\title{
Research of the Structure of Nanomaterials by Analysis of Micromorphology Images
}

\author{
Y. Suchikova, I. Bogdanov, S. Kovachov, H. Lopatina, N. Tsybuliak, \\ and N. Panova
}

Berdyansk State Pedagogical University, 4, Schmidt Str., 71100 Berdyansk, Ukraine

The modern challenge of materials science is the analysis of the surface of nanostructures, which is complicated by the small sizes of the nanoobjects and their number. In the presented study, we demonstrate a technique for evaluating the basic indices of the micromorphology of porous surfaces by analysing the microscopic image of the surface. Image processing and analysis software packages, such as ImageJ and Origin, are used for optimization, automation, and accuracy of analysis. Such an analysis allows us to evaluate the surface of nanostructures by various indicators: the shape and number of nanoobjects, their location and distribution by diameter, perimeter, etc. In addition, modelling the growth of nanoobjects in the depth of the crystal allows to trace the dynamics of the nanostructures' synthesis process and to design nanostructures with predetermined parameters. Such studies are necessary to ensure reproducibility, uniformity, and accuracy of experiments for the fabrication of nanostructures at an industrial scale.

Сучасним викликом матеріялознавства є аналіза поверхні наноструктур, що ускладнюється малим розміром нанооб'єктів та їхньою кількістю. У представленому дослідженні ми демонструємо методику оцінювання основних показників мікроморфології поруватих поверхонь шляхом аналізи мікроскопічного зображення поверхні. Для оптимізації, автоматизації та точности аналізи було застосовано програмні пакети оброблення й аналізи зображень і масиву даних, а саме, ImageJ та Origin. Така аналіза уможливлює оцінювати поверхню наноструктур за різними показниками: формою та кількістю нанооб'єктів, їхніми розташуванням і розподілом за діяметром, периметром тощо. Моделювання росту нанооб'єктів вглибину кристалу уможливлює простежити динаміку процесу синтези наноструктур і створювати наноструктури із заздалегідь заданими параметрами. Такі дослідження потрібні для забезпечення відтворюваности, однорідности та точности експериментів для виготовлення наноструктур у промисловому масштабі. 
Key words: nanostructures, image processing, microscopy, micromorphology, statistical processing.

Ключові слова: наноструктури, оброблення зображень, мікроскопія, мікроморфологія, статистичне оброблення.

(Received 8 November, 2019)

\section{INTRODUCTION}

Nanotechnology has long occupied leading positions in terms of studies $[1,2]$. These studies relate to methods of synthesis [3, 4], the chemical and physical properties [5, 6] application [7, 8], and environmental risks $[9,10]$. Interest in nanostructured materials every year is only increasing, as evidenced by the increasing number of publications and patents [11]. Such an interest leads to the improvement of not only synthesis technologies $[12,13]$, but also methods of researching nanomaterials [14] and their properties [15]. The researchers' attention is focused on the chemical [16], optical [17], electrical [18], physical [19] properties of nanomaterials.

The peculiarity of nanostructures is that all these properties can be radically different from the properties of structures in monophase [20]. This is due to quantum-size effects [21], which are brought to light in the transition of geometrical parameters of the structure to the nanoscale [22]. Detection of the experimental characteristics of nanostructured surfaces is one of the key tasks of modern documentary science, which investigated the process of creating nanomaterials and products at their level [23, 24]. Therefore, of the key methods for studying nanostructures, there are methods related to the analysis of microscopic images [25]. Images of nanostructures obtained by microscopy allow us to estimate the type of nanostructure [26], the presence of additional phases [27], the size and shape of nanocrystallites [28], the uniform distribution of them over the surface [29], and so on. However, very often such an analysis is purely descriptive in nature [30], while a contemporary complex is research aimed at obtaining a large body of data comparison, verification, and statistical analysis of research results.

This is conditioned, first of all, by need to predict the properties of nanostructures during their formation and synthesis of nanomaterials with predetermined parameters [31, 32].

The implementation of high-quality analysis is associated with known difficulties, which are caused by:

- subjectivity of observations [33];

- low speed of the research process [34];

— the complexity of conducting research [35]; 
— the necessity of applying statistical methods [36];

- the need to use high-value equipment [37], etc.

Therefore, a simple analysis of nanoobjects photos taken with microscopes is often not enough.

Since small changes in the analysis and processing of images have a great impact on the subsequent fate of the finished product [38], the methods of non-destructive and rapid control, which determine and analyse these changes [39], can be successfully used as a tool for quality control of nanostructures.

The evaluation of the properties of the microstructure of materials has a dual purpose: on the one hand, it is an assessment of the adequacy of the process of managing the structure [40]; on the other hand, it is to ensure the optimum quality of the finished product [41].

The purely visual analysis of the samples under study does not provide complete and accurate information regarding the size of the nanoobjects and their density.

Today, there are many techniques for measuring the size of nanoobjects [42]. However, most of them are based on measuring the size of each object separately [43]. Such an approach is time consuming and requires a lot of time [44]. Under these conditions, it is almost impossible to investigate the distribution of particles or pores by size, to establish statistical regularities, etc.

In addition, the results of such work are, in most cases, dependent on the subjective judgment of the researcher, and as a result may contain a large number of faults and significant errors [45]. They may differ from one researcher to another and have poor reproducibility [46].

In this regard, microscope manufacturers develop special programs for the study of microscopic images in situ [47]. However, these programs are costly, applied to a particular brand of microscopes, and are often difficult to use [48].

Such programs work mainly with the electronic image of the sample [49], which is in the microscope at this time.

In practice, it is often necessary to analyse the image without the sample itself (over time or for any other reason). Therefore, it is appropriate to choose a program that lets you work with objects photomicrographs obtained using different types of microscopes.

With this in mind, programs that can work with an image rather than a real-time sample, i.e., in vitro, are becoming more common.

There are all necessary for the processing of microscopic images algorithms in the arsenal of these programs:

- high-frequency and low-frequency filtering [50];

— selection of image borders [51];

- arithmetic and logic operations [52];

- brightness/contrast correction, etc. [53].

Image processing in this case is not aimed at improving visual per- 
ception, but at preparing it for further analysis [54].

In all applications of this specificity, a certain sequence of algorithms is proposed for processing and obtaining characteristics of the studied sample structure [55].

Despite the level achieved in the analysis of microscopic images, there are a number of problems. These problems may be due to poor image quality, microscope resolution limit, imperfect data processing techniques, and more.

The goal of this study is to analyse and improve techniques for analysing micrographs of nanostructures using software packages that allow us to evaluate nanoobjects with accuracy sufficient to identify and build nanostructures statistical dependences.

\section{MATERIALS AND METHODS}

The plate of indium phosphide synthesized on the surface of porous layer was used as the test sample.

The porous layer was formed by the method of anode electrochemical etching by immersing the semiconductor in a fluoroplastic cell filled with electrolyte [56]. The etching conditions were selected as follows: $10 \mathrm{H}_{2} \mathrm{O}+1 \mathrm{HCl}$ electrolyte; etching time $t=20 \mathrm{~min}$, current density $j=150 \mathrm{~mA} / \mathrm{cm}^{2}$.

The raster electron microscope JEOL-6490 was used to analyse the morphology of the investigated nanostructured sample. Image preparation and analysis were performed using ImageJ and Origin.

\section{RESEARCH METHODOLOGY}

The objectives of the analysis of micrographs of the surface of nanostructures in the general case are:

- statistical processing of object characteristics obtained in the measurement process [57];

- determination of average values of the obtained quantities [58];

- construction of graphical dependences for visualization of the analysis process [59].

It is necessary to select the main stages for qualitative analysis of micromorphology of nanostructures (Fig. 1). First of all, the crucial point is the presence of a quality image obtained with a microscope. The choice of areas for analysis and optimal increase is an important point here. It will be difficult to identify too small surface elements with insufficient magnification. The image quality will be lost at too high magnification. Therefore, the first step will consist of two key steps: selecting the sample area for analysis and selecting the optimal magnification value. 


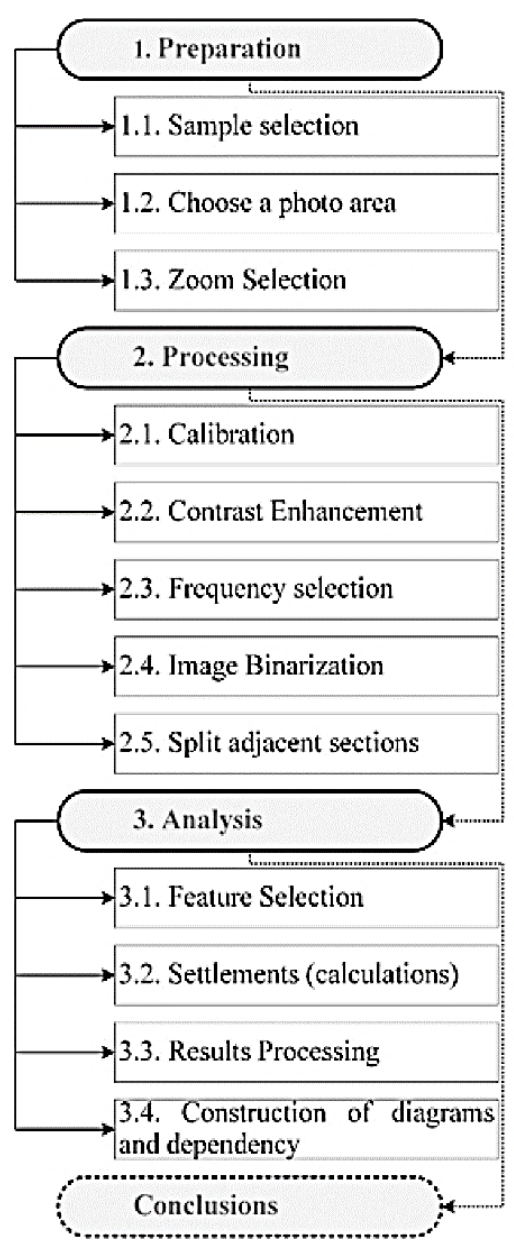

Fig. 1. General scheme of analysis of morphology of nanostructures.

Photos taken with a microscope tend to lack contrast. Therefore, it is necessary to prepare the resulting image for analysis. For this, the image must be opened in ImageJ and calibrated [60]. To increase the contrast of pore boundaries, it is advisable to use the Bandpass filter using the Fourier transform [61]. It will allow removing both high and low spatial frequencies in the image. In doing so, it is necessary to experimentally select the cut-off frequency levels. This provides the most contrasting image. Therefore, the most contrasting image is provided. It is advisable to use the Watershed algorithm for the separation of adjacent crystallites and pores with fuzzy boundaries [62]. Before processing the image according to this algorithm, the photo is prebinarized for the transition from grayscale to two-colour image [63].

Further analysis of the morphology of the sample is carried out. It is 
necessary to choose the characteristics to be tested for this. The ImageJ program automatically calculates. In addition, using ImageJ, we can hold the count (Count) of analysed particles, their perimeter (Perimeter), average size (Average size) and solidity (Solidity), which characterizes the ratio of the area of the selected section to the total area, the distribution of particle size, etc. [64, 65].

The program calculates the number of pores in the selected area, however, the pores located on the boundary of the image, it is advisable to count according to the following rule: the pores are counted only on two adjacent sides of the rectangle; on the other two sides, the pores are not taken into account. According to the obtained data, diagrams are drawn and conclusions are made.

\section{RESULTS AND DISCUSSION}

Figure 2 shows the micrograph of porous indium phosphide sample obtained using the scanning electron microscope JEOL-6490. According to the analysis of visual images SEM, the pores are round, most of the pores are isolated from one another, and are uniformly across the surface. In some areas, the pores form etched grooves due to the fact that they fit snugly along each other along the straight lane. These bands can be surface defects in the specimen (microscratches) and growth defects (impurity segregation lines).

A two-dimensional image obtained with a microscope can be imagined as a matrix whose indices describe the numbers of rows and columns, and the numerical values of the elements characterize the intensity of colour [66]. The main parameters characterizing a digital image are its resolution (the number of pixels in the original image and the colour depth) [67].

Figure 3, $a-c$ demonstrates bitmap processing of micrographs performed in ImageJ [261]. Such a treatment is performed to analyse the surface according to the selected morphological characteristic (in our case, the pore diameter and surface porosity). Further, the program automatically calculates the number of pores (Fig. 3, c), their diameter and the surface area occupied by the pores (i.e., surface porosity).

ImageJ has a $3 D$-image modelling feature. For this, the sections of the REM image are coloured differently depending on the intensity of the black colour. The program draws a diagram of the distribution of these sites by the area of surface coverage, which allows estimating the area of untreated areas and etched with different depth (Fig. 4). Figure 5 shows the simulation results.

The analysis of the conducted simulation (Fig. 5) leads to the conclusion that the pores in this case move into the depth of the sample with long parallel channels. Branching of pores below the surface is not observed. Such behaviour is typical of indium phosphide crystals with a surface ori- 


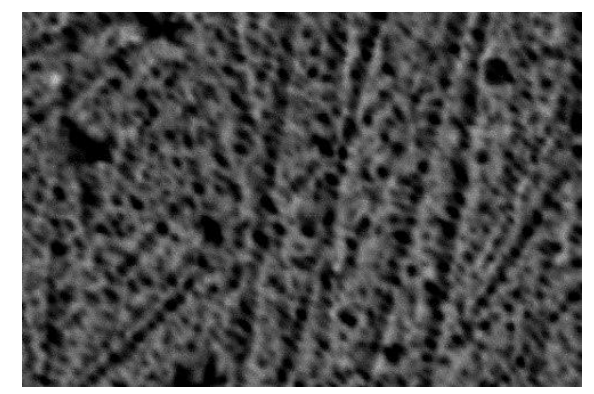

Fig. 2. Morphology Por-InP: electrolyte $10 \mathrm{H}_{2} \mathrm{O}+1 \mathrm{HCl}$; etching time $t=20$ min; current solidity $j=150 \mathrm{~mA} / \mathrm{cm}^{2}$.

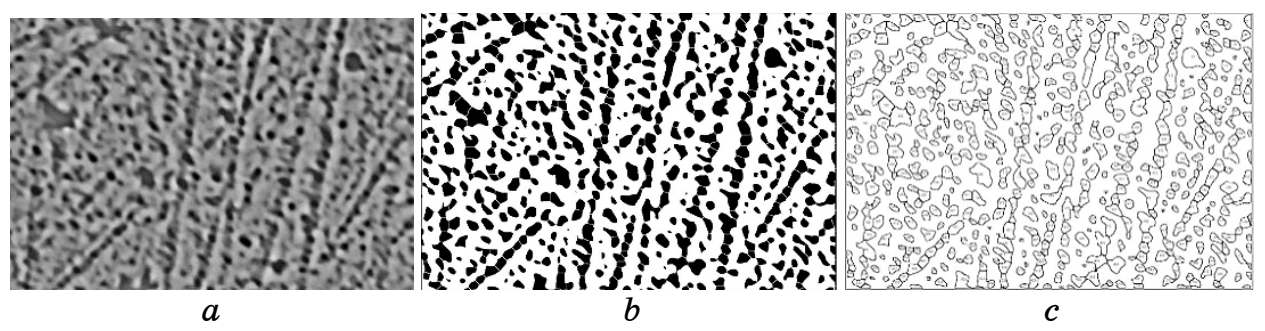

Fig. 3. Results of sequential processing of microscopic image of por-InP surface: $a$-Bandpass filter; $b$-binarization and Watershed algorithm; $c-$ calculation of the average crystallite size.

entation (100) that has been confirmed by several studies [68, 69].

For the area of the test sample, the number of pores was calculated (there were 558 of them) and their distribution by diameter was made (Fig. 6).

Determination of the Main Characteristics of the Pore Shape. The concept of circularity, which can be implemented by several methods, is used to describe one of the main characteristics of pore shape in the program.

The first method of estimating the factor of the pore shape, namely, circularity (Circularity), involves the calculation by the formula:

$$
F_{\phi}=\frac{4 \pi S}{p^{2}},
$$

where $S$ is the pore area, $p$ is the perimeter of the pore.

The value of the form factor $F_{\phi}=1$ indicates that the pore section is an ideal circle. The closer the value of roundness to 0 , the more elongated or deformed the pore section will be.

The second method of Round estimation is based on the expression: 


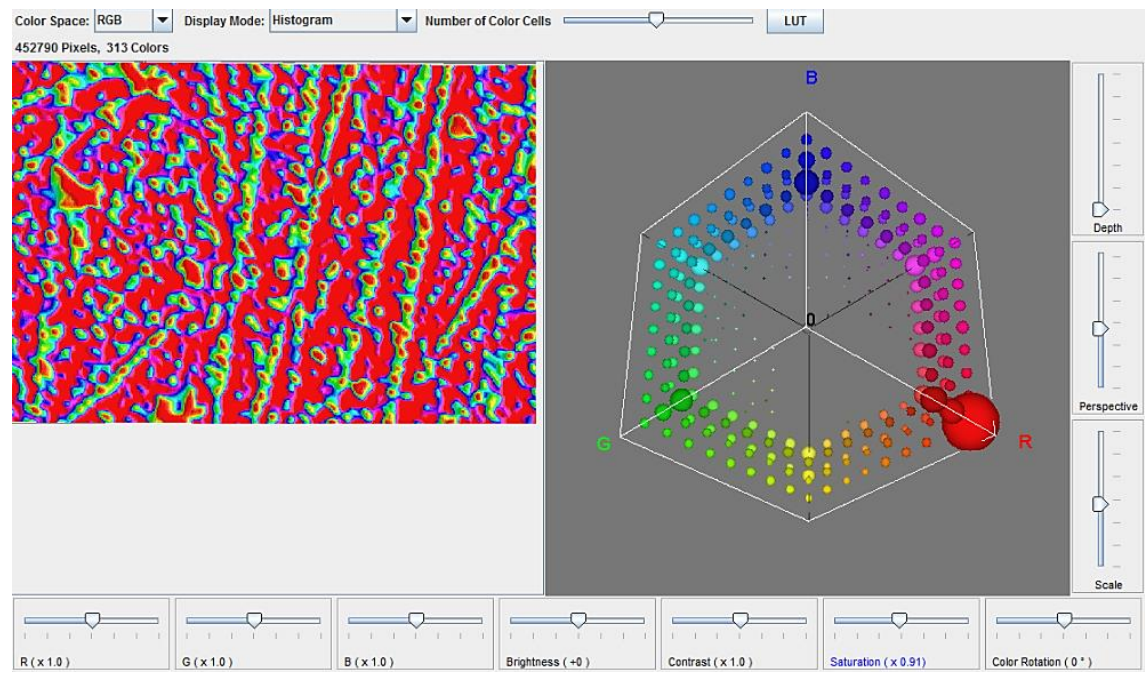

Fig. 4. The SEM-image colorization and intensity chart of the sample surface por-InP etching, made in the program ImageJ.
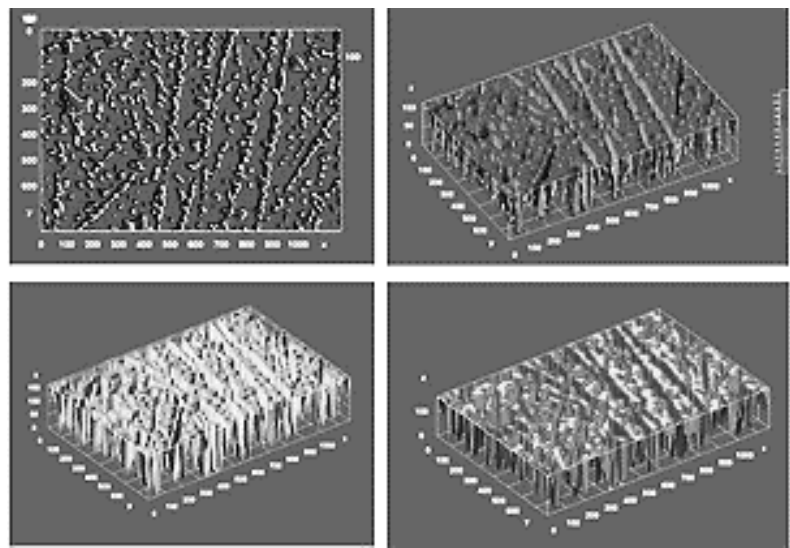

Fig. 5. Modelling of pore growth in depth of the sample, made in ImageJ.

$$
F_{R}=\frac{4 S}{\pi l_{\max }^{2}},
$$

where $l_{\max }$ is the larger axis of the pore.

Both methods provide identical results for pores that have the crosssectional shape of the correct circle. For pores and digestive pits whose shape deviates significantly from the circle, the aspect ratio (AR) is used, which shows the magnitude of the ratio of the major axis to the smaller one. 


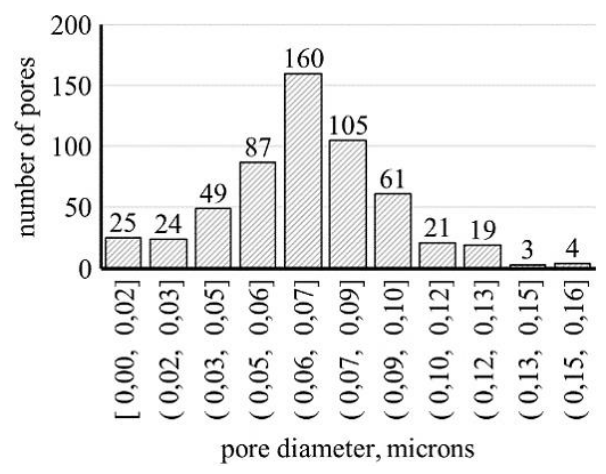

Fig. 6. Histogram distribution of pore diameter, por-InP sample.

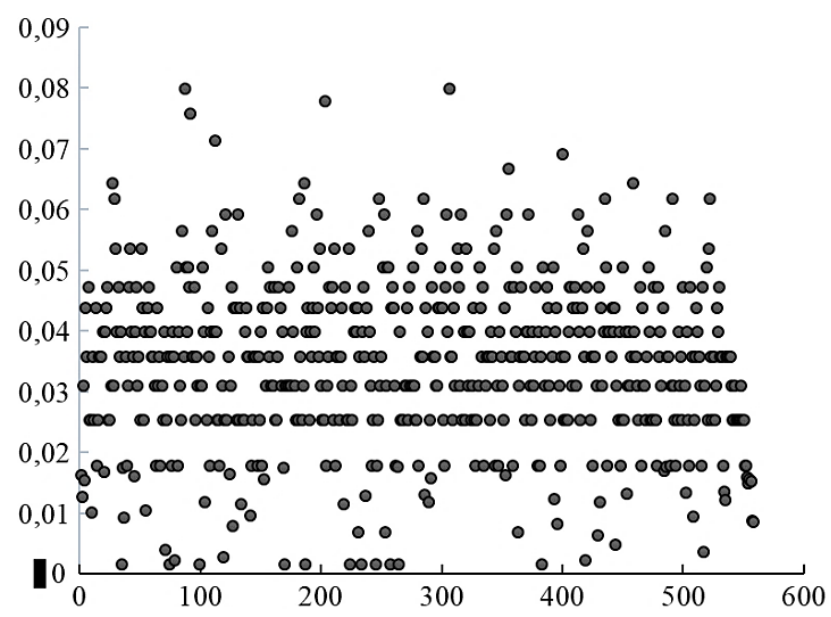

Fig. 7. Diagram of pore diameter distribution.

As an example, Table 1 shows the results of determining the basic quantitative characteristics of the sample, obtained on the basis of the analysis of the microstructure of por-InP (100).

The results of the generalized analysis of these characteristics for the section of the porous surface 20 of the samples tested and synthesized under similar conditions also show almost complete coincidence of these characteristics (Table 2).

The analysis allows describing morphological parameters of nanostructures with high accuracy. The pores by area are distributed according to normal law. The area of most of them $(86 \%)$ is in the range (0.03-0.12) microns, indicating that the surface is macroporous. The shape of the pores approaches the round, but is not. In addition, some pores tend to merge.

Thus, the presented method of analysis of nanostructured surfaces 
TABLE 1. Quantitative characteristics of the morphological parameters of the surface of por-InP (100) (fragment).

\begin{tabular}{c|c|c|c|c|cc}
\hline No. & Area, $\mu \mathrm{m}^{2}$ & Perimeter, $\mu \mathrm{m}$ & $\begin{array}{c}\text { Form } \\
\text { factor }\end{array}$ & Circularity & $\begin{array}{c}\text { Aspect } \\
\text { ratio }\end{array}$ & $\begin{array}{c}\text { Integrity, } \\
\text { firmness }\end{array}$ \\
\hline 1 & 0.005 & 0.293 & 0.690 & 0.522 & 1.917 & 0.954 \\
2 & 0.006 & 0.327 & 0.708 & 0.629 & 1.591 & 0.887 \\
3 & 0.007 & 0.331 & 0.793 & 0.673 & 1.485 & 0.918 \\
4 & 0.002 & 0.161 & 0.848 & 0.603 & 1.659 & 0.921 \\
5 & 0.002 & 0.177 & 0.868 & 0.804 & 1.243 & 0.935 \\
6 & 0.003 & 0.220 & 0.767 & 0.687 & 1.455 & 0.929 \\
7 & 0.013 & 0.567 & 0.501 & 0.443 & 2.257 & 0.790 \\
8 & 0.003 & 0.197 & 0.850 & 0.840 & 1.191 & 0.936 \\
9 & 0.012 & 0.530 & 0.558 & 0.710 & 1.408 & 0.860 \\
10 & 0.009 & 0.387 & 0.745 & 0.675 & 1.481 & 0.931 \\
11 & 0.005 & 0.299 & 0.724 & 0.516 & 1.938 & 0.915 \\
12 & 0.007 & 0.363 & 0.683 & 0.707 & 1.414 & 0.908 \\
13 & 0.004 & 0.278 & 0.681 & 0.399 & 2.503 & 0.928 \\
14 & 0.005 & 0.323 & 0.567 & 0.456 & 2.193 & 0.902 \\
$\ldots$ & $\ldots$ & $\ldots$ & $\ldots . .6$ & $\ldots$ & $\ldots$ & $\ldots$ \\
The average & 0.0516 & 0.294 & 0.723 & 0.671 & 1.604 & 0.894 \\
$\begin{array}{c}\text { Standard } \\
\text { deviation }\end{array}$ & 0.0063 & 0.104 & 0.114 & 0.175 & 0.451 & 0.0567 \\
Standard & 0.00114 & 0.0189 & 0.0208 & 0.0319 & 0.0824 & 0.0103 \\
error & & & & & & \\
Marginal & 0.00233 & 0.0387 & 0.0424 & 0.0651 & 0.168 & 0.0211 \\
error & & & & & &
\end{tabular}

TABLE 2. Averages for 20 por-InP samples.

\begin{tabular}{|c|c|c|c|c|c|c|}
\hline Parameter & Area, $\mu \mathrm{m}^{2}$ & Perimeter, $\mu \mathrm{m}$ & $\begin{array}{l}\text { Form } \\
\text { factor }\end{array}$ & Circularity & $\begin{array}{l}\text { Aspect } \\
\text { ratio }\end{array}$ & Integrity \\
\hline \multirow{2}{*}{$\begin{array}{c}\text { The average } \\
\text { Standard } \\
\text { deviation }\end{array}$} & 0.0532 & 0.324 & 0.652 & 0.587 & 1.511 & 0.953 \\
\hline & 0.0071 & 0.111 & 0.098 & 0.165 & 0.402 & 0.0687 \\
\hline
\end{tabular}

using computer programs for microscopic imaging allows us to identify the type of nanostructure, the nature of the distribution of nanocrystallites/pores by area, effective diameter, perimeter and shape.

Such studies are necessary, first of all, to evaluate the quality of nanostructures, to study the convergence and reproducibility of methods for synthesis of nanomaterials with established quality levels, to compare samples and to identify defects. In addition, the statistical processing of the data obtained from the analysis of nanostructured images allows us to trace the systematic or random nature of the appearance of defective areas on the surface, which gives an understanding of the kinetics of the nanostructures synthesis process and the 
mechanisms under which nanostructuring occurs. The issues of nanostructures modelling and the study of correlations between technological factors of synthesis and morphological indices of nanostructures need further research.

\section{CONCLUSIONS}

The study presents the methodology of evaluation of nanostructures by analysing the microscopic images using software and statistical methods of processing results. As an example, the analysis of nanostructure of porous indium phosphide was performed by the pores, transverse diameter, number of pores, and their perimeter, so on. It is established that the distribution of pores by area is subject to normal distribution. The nanostructure can be classified as macroporous; the pores are mutually parallel cylindrical holes. This analysis allows us to evaluate nanoobjects with accuracy sufficient to identify nanostructures and construct statistical dependencies. This analysis allows us to evaluate nanoobjects with accuracy sufficient to identify nanostructures and construct statistical dependences.

\section{ACKNOWLEDGEMENT}

This study was performed within the framework of scientific statefunded research: 'Development of Technology for the Evaluation of Quality and Safety Indicators of Nanotechnologies Products throughout Their Life Cycle' (State Registration Number 0117U003860).

\section{REFERENCES}

1. B. Karn, T. Kuiken, and M. Ott, Environmental Health Perspectives, 117, No. 12: 1813 (2009). https://doi.org/10.1289/ehp.0900793

2. $\quad$ C. Li, J. Lin, J. Mater. Chem., 20, No. 33: 6831 (2010). https://doi.org/10.1039/C0JM00031K

3. Y. Shi and B. Zhang, Chemical Society Reviews, 45, No. 6: 1529 (2016). https://doi.org/10.1039/C5CS00434A

4. S.-T. Ha, R. Su, J. Xing, Q. Zhang, and Q. Xiong, Chem. Sci., 8, No. 4: 2522 (2017). https://doi.org/10.1039/C6SC04474C

5. Y. Guo, K. Xu, Ch. Wu, J. Zhao, and Y. Xie, Chemical Society Reviews, 44, No. 3: 637 (2015). https://doi.org/10.1039/C4CS00302K

6. J. Wan, S. D. Lacey, Ji. Dai, W. Bao, M. S. Fuhrer, and L. Hu, Chemical Society Reviews, 45, No. 24: 6742 (2016). https://doi.org/10.1039/C5CS00758E

7. H. Yi, D. Huang, L. Qin, G. Zeng, C. Lai, M. Cheng, Sh. Ye, B. Song, X. Ren, and X. Guo, Applied Catalysis B: Environmental, 239: 408 (2018). https://doi.org/10.1016/j.apcatb.2018.07.068

8. Y. Suchikova, Eastern-European Journal of Enterprise Technologies, 84, No. 
6/5: 26 (2016). https://doi.org/10.15587/1729-4061.2016.85848

9. S. Vambol, V. Vambol, I. Bogdanov, Y. Suchikova, and N. Rashkevich, Eastern European Journal of Enterprise Technologies, 90, No. 6/10: 57 (2017). https://doi.org/10.15587/1729-4061.2017.118213

10. P. Laux, J. Tentschert, Ch. Riebeling et al., Arch Toxicol, 92, No. 1: 121 (2018). https://doi.org/10.1007/s0020

11. Nanotechnology Products Database (NPD). http://product.statnano.com/

12. I. Bogdanov, Y. Suchikova, S. Vambol, V. Vambol, O. Kondratenko, O. Hurenko, and S. Onishchenko, Eastern-European Journal of Enterprise Technologies, 3 , No. 5 (87): 37 (2017). https://doi.org/10.15587/1729-4061.2017.104039

13. Y. O. Suchikova, Journal of Nano- and Electronic Physics, 9, No. 1: 1006-1 (2017). https://doi.org/10.21272/jnep.9(1).01006

14. B. Liu and K. Zhou, Progress in Materials Science, 100: 99 (2018).

15. P. Figueiredo, K. Lintinen, J. T. Hirvonen, M. A. Kostiainen, and H. A. Santos, Progress in Materials Science, 93: 233 (2018). https://doi.org/10.1016/j.pmatsci.2017.12.001

16. G. Khrypunov, S. Vambol, N. Deyneko, and Y. Suchikova, Eastern-European Journal of Enterprise Technologies, 6, No. 5 (84): 12 (2016). https://doi.org/10.15587/1729-4061.2016.85617

17. Y. A. Suchikova, V. V. Kidalov, A. A. Konovalenko, and G. A. Sukach, ECS Transactions, 25, No. 24: 59 (2010).

18. J. Wang, R. Chen, L. Xiang, and S. Komarneni, Ceramics International, 44, No. 7: 7357 (2018). https://doi.org/10.1016/j.ceramint.2018.02.013

19. Y. A. Suchikova, V. V. Kidalov, and G. A. Sukach, Journal of Nano- and Electronic Physics, 1, No. 4: 111 (2009).

20. K. Omri, A. Bettaibi, K. Khirouni, and L. El Mir, Condensed Matter, 537: 167 (2018). https://doi.org/10.1016/j.physb.2018.02.025

21. S. Vambol, I. Bogdanov, V. Vambol, Y. Suchikova, H. Lopatina, and N. Tsybuliak, Eastern-European Journal of Enterprise Technologies, 6, No. 5 (90): 22 (2017). https://doi.org/10.15587/1729-4061.2017.118725

22. L. Huang, D. Santiago, P. Loyselle, and L. Dai, Small, 14, No. 43: 1800879 (2018). https://doi.org/10.1002/smll.201800879

23. S. Vambol, V. Vambol, Y. Suchikova, I. Bogdanov, and O. Kondratenko, Journal of Achievements in Materials and Manufacturing Engineering, 86, No. 2: 49 (2018).

24. S. O. Vambol, I. T. Bohdanov, V. V. Vambol, Y. O. Suchikova, O. M. Kondratenko, T. P. Nestorenko, and S. V. Onyschenko, Journal of Nano- and Electronic Physics, 9, No. 6: 06016-1(2017). https://doi.org/10.21272/jnep.10(4).04020

25. Ya. Suchikova, Handbook of Nanoelectrochemistry: Electrochemical Synthesis Methods, Properties, and Characterization Techniques (Eds. M. Aliofkhazraei and A. S. H. Makhlouf) (Cham: Springer: 2016), p. 283. https://doi.org/10.1007/978-3-319-15266-0_28

26. H. Choi, H. Kim, S. Hwang, W. Choi, and M. Jeon, Solar Energy Materials and Solar Cells, 95, No. 1: 323 (2011). https://doi.org/10.1016/j.solmat.2010.04.044

27. Y. Wang et al, Chem. Eng. J., 358: 74 (2019). https://doi.org/10.1016/j.cej.2018.10.002

28. J. Zhang, H. Li, Q. Kuang, and Z. Xie, Accounts Chem Res, 51, No. 11: 2880 (2018). https://doi.org/10.1021/acs.accounts.8b00344 
29. Y. Suchikova, I. Bogdanov, S. Onishchenko, S. Vambol, V. Vambol, and O. Kondratenko, Proc. of the 2017 IEEE 7th International Conference on Nanomaterials: Applications and Properties (NAP-2017) (September 10-15, 2017 ) (Sumy, Ukraine: 2017), p. 138.

30. Y. A. Suchikova, V. V. Kidalov, G. A. Sukach, Journal of Nano- and Electronic Physics, 2, No. 4: 142 (2010).

31. H. Fraoucene, D. Hatem, F. Vacandio, and M. Pasquinelli, Nanoscience \& Nanotechnology-Asia, 9, No. 1: 121 (2019). https://doi.org/10.2174/2210681208666180411154247

32. H. Aydın, F. Yakuphanoglu, and C. Aydın, J. Alloys Compd., 773: 802 (2019). https://doi.org/10.1016/j.jallcom.2018.09.327

33. A. A. Thahe, N. Bidin, M. A. Al-Azawi, and N. M. Ahmed, Jurnal Teknologi, 78, No. 3: 60 (2016). https://doi.org/10.11113/jt.v78.7465

34. R. Tenne, U. Rossman, B. Rephael, Y. Israel, A. Krupinski-Ptaszek, R. Lapkiewicz, Y. Silberberg, and D. Oron, Proc. of SPIE 10934, Optical, Opto-Atomic, and Entanglement-Enhanced Precision Metrology (February 2-7, 2019) (San Francisco, United States: 2019), p. 109341.

35. K. Lima, Ch. Roppa, S. Barika, J. Fourkase, B. Shapirof, and E. Waksa, Nano Lett., 16, No. 9: 5415 (2016). https://doi.org/10.1021/acs.nanolett.6b01708

36. C. Kizilyaprak, A. G. Bittermann, J. Daraspe, and B. M. Humbel, Methods Mol. Biol., 1117: 541 (2014). https://doi.org/10.1007/978-1-62703-776-1_24

37. C. Villinger, H. Gregorius, C. Kranz, K. Hoehn, C. Muenzberg, G. von Wichert, B. Mizaikoff, G. Wanner, and P. Walther, Histochem. Cell Biol., 138: 549 (2012). https://doi.org/10.1007/s00418-012-1020-6

38. Z. S. Tang, N. Bolong, I. Saad, R. Ramli, and F. T. Y. Lim, Jurnal Teknologi, 78, No. 12: 19 (2016).

39. G. Güven and A. B. Oktay, $26^{\text {th }}$ Signal Processing and Communications Applications Conference (SIU) (Izmir, Turkey: IEEE: 2018).

40. N. P. Yadav, X. Liu, W. Wang, K. Ullah, and B. Xu, J. Phys.: Conference Series. IOP Publishing, 844, No. 1: (2017).

41. K. Yang, Y. Tang, S. Hu, and C. Chen, Proc. of $9^{\text {th }}$ International Symposium on Advanced Optical Manufacturing and Testing Technologies: Meta-SurfaceWave and Planar Optics, International Society for Optics and Photonics (2019), p. 10841.

42. K. Yang, G. Yang, L. Chen, L. Cheng, L. Wang, C. Ge, and Z. Liu, Biomaterials, 38: 1 (2015). https://doi.org/10.1016/j.biomaterials.2014.10.052

43. X. Wu, H. Li, and N. Xiao, J. Photochem. Photobiol. B: Biology, 187: 89 (2018). https://doi.org/10.1016/j.jphotobiol.2018.07.015

44. J. E. Belizário, B. A. Sangiuliano, B. Viana-Santos, M. Pérez-Sosa, and I. Caldeira, Technology, 5, No. 2: 61 (2017). https://doi.org/10.1142/S2339547817300037

45. X. Wu, H. Li, and N. Xiao, J. Photochem. Photobiol. B: Biology, 187: 89 (2018). https://doi.org/10.1016/j.jphotobiol.2018.07.015

46. P. Kunicki, Z. W. Kowalski, and T. Gotszalk, Przeglad Elektrotechniczny, 92, No. 8: 21 (2016). https://doi.org/10.15199/48.2016.08.06

47. T. Epicier, S. Koneti, P. Avenier, A. Cabiac, A. S. Gay, and L. Roiban, Catal. Today, 334, No. 15: 68 (2019). https://doi.org/10.1016/j.cattod.2019.01.061

48. S. M. Ghodsi, S. Anand, R. Shahbazian-Yassar, T. Shokuhfar, and C. M. Megaridis, ACS Nano, 13, No. 4: 4677 (2019). 
https://doi.org/10.1021/acsnano.9b00914

49. S. Y. Guan, H. S. Liao, B. J. Juang, S. C. Chin, T. M. Chuang, and C. S. Chang, Ultramicroscopy, 196: 180 (2019).

https://doi.org/10.1016/j.ultramic.2018.10.008

50. A. M. Nazif and M. D. Levine, IEEE Transactions on Pattern Analysis and Machine Intelligence, 5: 555 (1984).

https://doi.org/10.1109/TPAMI.1984.4767570

51. G. Wolberg, CA: IEEE Computer Society Press (Los Alamitos: 1990), p. 10662.

52. J. L. Mundy, IEEE Expert, 10, No. 6: 64 (1995). https://doi.org/10.1109/64.483254

53. Science of Microscopy (Eds. P. W. Hawkes and J. C. H. Spence) (Springer Science \& Business Media: 2008), p. 1228.

54. J. Bednarek, Probl. Forensic. Sci., 56: 65 (2004).

55. A. Kazak, S. Chugunov, and A. Chashkov, International Multidisciplinary Scientific GeoConference: SGEM-Surveying Geology \& Mining Ecology Management, 17, Nos. 1-4: 821 (2017). https://doi.org/10.5593/sgem2017/14

56. Handbook of Nanoelectrochemistry: Electrochemical Synthesis Methods, Properties, and Characterization Techniques (Eds. M. Aliofkhazraei and A. S. H. Makhlouf) (Cham: Springer: 2016). https://doi.org/10.1007/978-3319-15266-0

57. S. Mollazadeh, J. Javadpour, and A. Khavandi, Ceram. Int., 33, Iss. 8: 1579 (2007). https://doi.org/10.1016/j.ceramint.2006.06.006

58. Y. Zhang, IEEE Computer Graphics and Applications, 16, No. 4 : 34 (1996). https://doi.org/10.1109/38.511850

59. P. Schneider, M. Meier, R. Wepf, and R. Mueller, Bone, 49: 304 (2011) https://doi.org/10.1016/j.bone.2011.04.005

60. M. D. Abramoff, P. J. Magalhães, and S. J. Ram, Biophotonics International, 11, No. 7: 36 (2004).

61. C. A. Schneider, W. S. Rasband, and K. W. Eliceiri, Nature Methods, 9, No. 7: 671 (2012). https://doi.org/10.1038/nmeth.2089

62. T. J. Collins, Biotechniques, 43, No. 1: 25 (2007). https://doi.org/10.2144/000112517

63. M. Doube, M. M. Kłosowski, I. Arganda-Carreras, F. P. Cordeliures, R. P. Dougherty, J. S. Jackson, B. Schmid, J. R. Hutchinson, and S. J. Shefelbine, Bone, 47, No. 6: 1076 (2010). https://doi.org/10.1016/j.bone.2010.08.023

64. T. Ferreira and W. Rasband, Image J Fiji, 1: 155 (2012).

65. U. Kuila and M. Prasad, Geophysical Prospecting, 61, No. 2: 341 (2013). https://doi.org/10.1111/1365-2478.12028

66. G. Binnig, H. Rohrer, C. Gerber, and E. Weibel, Phys. Rev. Lett., 49, No. 1: 57 (1982). https://doi.org/10.1103/PhysRevLett.49.57

67. J. S. Villarrubia, Journal of Research of the National Institute of Standards and Technology, 102, No. 4: 425 (1997). https://doi.org/10.6028/jres.102.030

68. P. A. Kohl, C. Wolowodiuk, and F. W. Ostermayer, J.Electrochem. Soc., 130, No. 11: 2288 (1983). https://doi.org/10.1149/1.2119571

69. N. Tarakina, Cryst. Growth Des., 12, No. 4: 1913 (2012). https://doi.org/10.1021/cg201636g 